\title{
Energy and reactivity profile and proton affinity analysis of rimegepant with special reference to its potential activity against SARS-CoV-2 virus proteins using molecular dynamics
}

\author{
T. Pooventhiran ${ }^{1}$ - Ephraim Felix Marondedze ${ }^{2}$ Penny Poomani Govender ${ }^{2}$. Utsab Bhattacharyya ${ }^{1}$. \\ D. Jagadeeswara Rao ${ }^{3}$. Elham S. Aazam ${ }^{4}$. Jinesh M. Kuthanapillil ${ }^{1} \cdot{\text { Tomlal Jose } E^{1} \cdot \text { Renjith Thomas }}^{1}$
}

Received: 3 March 2021 / Accepted: 18 August 2021 / Published online: 4 September 2021

(c) The Author(s), under exclusive licence to Springer-Verlag GmbH Germany, part of Springer Nature 2021

\begin{abstract}
Rimegepant is a new medicine developed for the management of chronic headache due to migraine. This manuscript is an attempt to study the various structural, physical, and chemical properties of the molecules. The molecule was optimized using B3LYP functional with 6-311G + (2d,p) basis set. Excited state properties of the compound were studied using CAM-B3LYP functional with same basis sets using IEFPCM model in methanol for the implicit solvent atmosphere. The various electronic descriptors helped to identify the reactivity behavior and stability. The compound is found to possess good nonlinear optical properties in the gas phase. The various intramolecular electronic delocalizations and non-covalent interactions were analyzed and explained. As the compound contain several heterocyclic nitrogen atoms, they have potential proton abstraction features, which was analyzed energetically. The most important result from this study is from the molecular docking analysis which indicates that rimegepant binds irreversibly with three established SARS-CoV-2 proteins with ID 6LU7, 6M03, and 6W63 with docking scores $-9.2988,-8.3629$, and $-9.5421 \mathrm{kcal} / \mathrm{mol}$ respectively. Further assessment of docked complexes with molecular dynamics simulations revealed that hydrophobic interactions, water bridges, and $\pi-\pi$ interactions play a significant role in stabilizing the ligand within the binding region of respective proteins. MMGBSA-free energies further demonstrated that rimegepant is more stable when complexed with 6LU7 among the selected PDB models. As the pharmacology and pharmacokinetics of this molecule are already established, rimegepant can be considered as an ideal candidate with potential for use in the treatment of COVID patients after clinical studies.
\end{abstract}

Keywords COVID $\cdot$ DFT $\cdot$ Rimegepant $\cdot$ Molecular docking $\cdot$ Proton affinity $\cdot$ Molecular dynamics

\section{Introduction}

The manuscript is dedicated to St Berchmans College on the occasion of its centenary (2021-22).

Renjith Thomas

renjith@sbcollege.ac.in

1 Department of Chemistry, St Berchmans College (Autonomous), Mahatma Gandhi University, Changanassery, Kerala, India

2 Department of Chemical Sciences, Doornfontein Campus, University of Johannesburg, P. O. Box 17011, Johannesburg 2028, South Africa

3 Department of Physics, Dr. Lankapalli Bullayya College, Visakhapatnam, Andhra Pradesh, India

4 Chemistry Department, Faculty of Science, King Abdulaziz University, Jeddah 23622, Saudi Arabia
Migraine is one of the major chronic disease affecting a large number of people throughout the globe [1]. Migraine reduces the quality of life and productivity, and limits the individual's participation in the social setup [2]. Usually, the migraine pain lasts between 4 and $72 \mathrm{~h}$, and causes nausea, vomiting, irritation towards light, and sometimes phonophobia [3]. The calcitonin gene-related peptide (CGRP) receptor was found to have a typical role in the onset of migraine and small drug molecules and antibodies are developed to antagonize this receptor [4, 5]. Also, humanized antibodies against CGRP or its receptor are being used as a prophylaxis measure in the management of migraine [6]. Rimegepant was developed as a CGRP receptor by using Heck reaction, and Hayashi-Miyaura and Ellman reactions [7]. Rimegepant is a heterocyclic system where the cyclohexane ring system 
was designed with the help of Heck reaction. The other two reactions were used to design chiral centers with aryl and amine groups. This is a relatively new drug as it was marketed in 2020 as a small-molecule blocker of CGRP by the Biohaven Pharmaceuticals of New Haven, Connecticut [8].

SARS due to $\mathrm{n}-\mathrm{CoV}-2$ is at present considered as a global pandemic that affected the life and economy of all countries around the world $[9,10]$. Vaccines have been developed to prevent this viral attack, but only a small fraction of the entire global population is fortunate enough to get them [11-13]. Once infected, it may cause serious effect on patients leading to SARS pneumonia and ultimately death. Even though drug development against this deadly disease is a matter of importance, new drug development is a timeconsuming process and hence, drug repurposing of existing drug molecules with known pharmacology and toxicity is a good idea. A lot of molecules are investigated as a probable candidate to treat the COVID related difficulties, but none of them is considered as a complete cure [14-20]. Computational methods have been extensively used for virtual screening and in silico screening of potential COVID-19 cures [21-23].

Remigepant is a newly marketed drug for the treatment of migraine. But its detailed electronic structure and reactivity are not reported elsewhere to the best of our knowledge. We used density functional theory to establish the structure and properties of the molecule. Also, we evaluated the intramolecular electron delocalizations, non-covalent interactions, and the average local ionization energy indices of the molecule. Also, we wanted to check whether this new drug is a probable candidate for drug repurposing for the management of the COVID-19. Jiang and co-workers already showed that this molecule is a potential inhibitor targeting 2'-O-ribose methyltransferase of SARS-CoV-2 [24]. In this manuscript, we report the structure and electronic features of this molecule and also molecular docking and molecular dynamics study of the compound was performed with three other established COVID protein targets.

\section{Methods}

\section{Quantum mechanical calculations}

Rimegepant molecule was optimized with Gaussian-09 [25] software using DFT-B3LYP[26] functional and $6-311 \mathrm{G}+(2 \mathrm{~d}, \mathrm{p})$ as a basis set. This optimized structure was used to study frontier molecular orbital (FMO) and nature bonding orbital (NBO). TD-DFT with RCAM-B3LYP [27] functional was used to simulate UV spectra and was visualized using GaussSum [28]. Rimegepant molecule has more than two reaction sites 1,2-difluorophenyl-, cycloheptapyrimidinamine-, piperidine-1-carboxylate-, and
2H-imidazopyridin-2-one groups. Reaction sites of rimegepant are calculated using Multiwavefunction [29] to prepare the electrostatic potential map [30], ALIE, and noncovalent interactions [31].

\section{Molecular docking studies}

Molecular docking was used to predict the binding affinity between the drug and different $\mathrm{COVID}^{-}$associated proteins, which was downloaded from the RCSB [32]. The COVID2-related proteins used in this study are PDBs: 6LU7, 6M03, and 6W63. The first one with ID 6LU7 represents the crystal structure of the main protease Mpro protein of the $n-\mathrm{CoV}_{-}-2$ [33]. $6 \mathrm{MO} 3$ is the COVID-19 main protease in apo form [34] and 6W63 is SARS coronavirus papain-like protease [35]. Docking was performed using Autodock Vina [36, 37] and visualized using BIOVA Discovery studio [38] and was confirmed using molecular dynamics simulations.

\section{Molecular dynamic studies}

Molecular dynamics simulations were executed using the GPU-accelerated Desmond software accessed through Schrodinger 2020 release 3 hosted by the Lengau Linux Cluster of the Centre for High Performance Computing South Africa [39, 40]. Before MD simulations, all models were downloaded from PDB and processed using the protein preparation wizard [40] available via the user interface Maestro version 12.5 [41]. Molecular dynamics simulation investigations were performed on undocked models (PDBs: 6LU7, 6M03, and 6W63) as well as their respective docked complexes for a timeframe of $400 \mathrm{~ns}$. Before production, all systems were allowed to relax using the default conditions of DESMOND as given in Maestro. During the production stage, trajectories were recorded at 100-ps intervals. As a result, 4004 frames were recorded. All simulations used a TIP5P solvent model in a 10- $\AA$ orthorhombic box using OPLS3e as the force field [42]. Three sodium ions were added to both $6 \mathrm{M} 03$ and $6 \mathrm{~W} 63$ whereas two sodium ions were added to $6 \mathrm{LU} 7$ systems to neutralize the positive charge and a physiological ion concentration of $0.15 \mathrm{M}$ as $\mathrm{NaCl}$ was applied to using the system builder during the $\mathrm{MD}$ setup stage. An NPT ensemble utilizing 1 atm pressure and $300 \mathrm{~K}$ temperature was employed. Herein, the pressure and temperature were controlled using the Martyna-Tobias-Klein [43] and the Nose-Hoover chain thermostat methods respectively [43]. For barostat conditions, the isotropic coupling style was set for a relaxation time of 2 ps. No restraints were applied, and all the other parameters were kept at default. Reversible reference system propagator algorithms (RESPA) integrators with a timestep of 2 fs (2.00 for near bonded and 6.00 for far bonded) were utilized. A cut-off radius of $9 \AA$ was used for both short-range electrostatic interactions 
such as Coulombic interactions and Van der Waals interactions. Long-range electrostatics were also treated with Particle Mesh Ewald (PME) using the default tolerance in Desmond. Post MD, various parameters such as protein-ligand interactions, root mean square deviation (RMSD), and root mean square fluctuation (RMSF), among others, were assessed. The Simulation Interaction Diagram tool available in Schrödinger Maestro was used for these parameters [41].

\section{Results and discussions}

\section{Geometry for rimegepant}

Rimegepant molecule structure was optimized by using density functional theory DFT-B3LYP as a method, and $6-311 \mathrm{G}+(2 \mathrm{~d}, \mathrm{p})$ as a basis set. Figure 1 shows the structure of rimegepant molecule and explains by its important bond angles and distances. The bond angles are 117.4278 and $118.7913^{0}$ for $1 \mathrm{~F}-30 \mathrm{C}-2 \mathrm{~F}-35 \mathrm{C}-30 \mathrm{C}$, respectively, and their bond distances are $1.3556,1.3524$, and $1.3679 \AA$ for $1 \mathrm{~F}-30 \mathrm{C}$, $2 \mathrm{~F}-35 \mathrm{C}$, and $3 \mathrm{O}-25 \mathrm{C}$ respectively. The bond distances for $3 \mathrm{O}-21 \mathrm{C}, 4 \mathrm{O}-25 \mathrm{C}, 6 \mathrm{~N}-25 \mathrm{C}, 6 \mathrm{~N}-18 \mathrm{C}$, and $6 \mathrm{~N}-19 \mathrm{C}$ having $1.4679,1.2225,1.3687,1.4643$, and $1.4631 \AA$, respectively, and their bond angles for $21 \mathrm{C}-3 \mathrm{O}-25 \mathrm{C}, 3 \mathrm{O}-25 \mathrm{C}-4 \mathrm{O}$, 4O-25C-6 N, 18C-6 N-25C, and 19C-6 N-25C partaking $115.7344,123.2764,124.4281,118.5318$, and $124.8133^{\circ}$ respectively. The bond angles are 124.2606, 126.1067, $127.4362,127.1117,111.0334,127.1832$, and $114.8730^{\circ}$ for $12 \mathrm{C}-7 \mathrm{~N}-27 \mathrm{C}, 12 \mathrm{C}-7 \mathrm{~N}-26 \mathrm{C}, 5 \mathrm{O}-27 \mathrm{C}-7 \mathrm{~N}, 5 \mathrm{O}-27 \mathrm{C}-10 \mathrm{~N}$, $27 \mathrm{C}-10 \mathrm{~N}-29 \mathrm{C}, 10 \mathrm{~N}-29 \mathrm{C}-11 \mathrm{~N}$, and $29 \mathrm{C}-11 \mathrm{~N}-39 \mathrm{C}$, respectively, and bond distances for $7 \mathrm{~N}-12 \mathrm{C}, 7 \mathrm{~N}-27 \mathrm{C}$, $7 \mathrm{~N}-26 \mathrm{C}, 5 \mathrm{O}-27 \mathrm{C}, 10 \mathrm{~N}-27 \mathrm{C}, 10 \mathrm{~N}-29 \mathrm{C}, 11 \mathrm{~N}-29 \mathrm{C}$, and $11 \mathrm{~N}-39 \mathrm{C}$ are $1.4683,1.4028,1.3943,1.2226,1.3934$, $1.3832,1.3190$, and $1.3509 \AA$ respectively. The bond angles for $17 \mathrm{C}-8 \mathrm{~N}-56 \mathrm{H}, 17 \mathrm{C}-8 \mathrm{~N}-57 \mathrm{H}$, and $23 \mathrm{C}-9 \mathrm{~N}-34 \mathrm{C}$ having 109.5901, and $109.9474^{\circ}$, respectively, and the bond distances are 1.4778, 1.0190, 1.0187, 1.3455, 1.3364, 1.5227, and 1,5323 for $8 \mathrm{~N}-17 \mathrm{C}, 8 \mathrm{~N}-56 \mathrm{H}, 8 \mathrm{~N}-57 \mathrm{H}, 9 \mathrm{~N}-23 \mathrm{C}$, $9 \mathrm{~N}-34 \mathrm{C}, 21 \mathrm{C}-23 \mathrm{C}$, and $20 \mathrm{C}-21 \mathrm{C}$ respectively.

\section{Frontier molecular orbital properties for rimegepant}

Rimegepant molecule structure was optimized by using density functional theory DFT-B3LYP as a method, and $6-311 G+(2 d, p)$ as a basis set. The frontier molecular orbitals (FMO) are mostly involved in reactions and explain the reactivity features of rimegepant [30, 44-47]. Frontier molecular orbital data can be effectively used to study reactivity information. Table 1 explains those important chemical descriptors. The frontier molecular orbitals are higher occupied molecular orbital (HOMO) and lower unoccupied molecular orbital (LUMO) energies are -6.5 and $-1.14 \mathrm{eV}$,

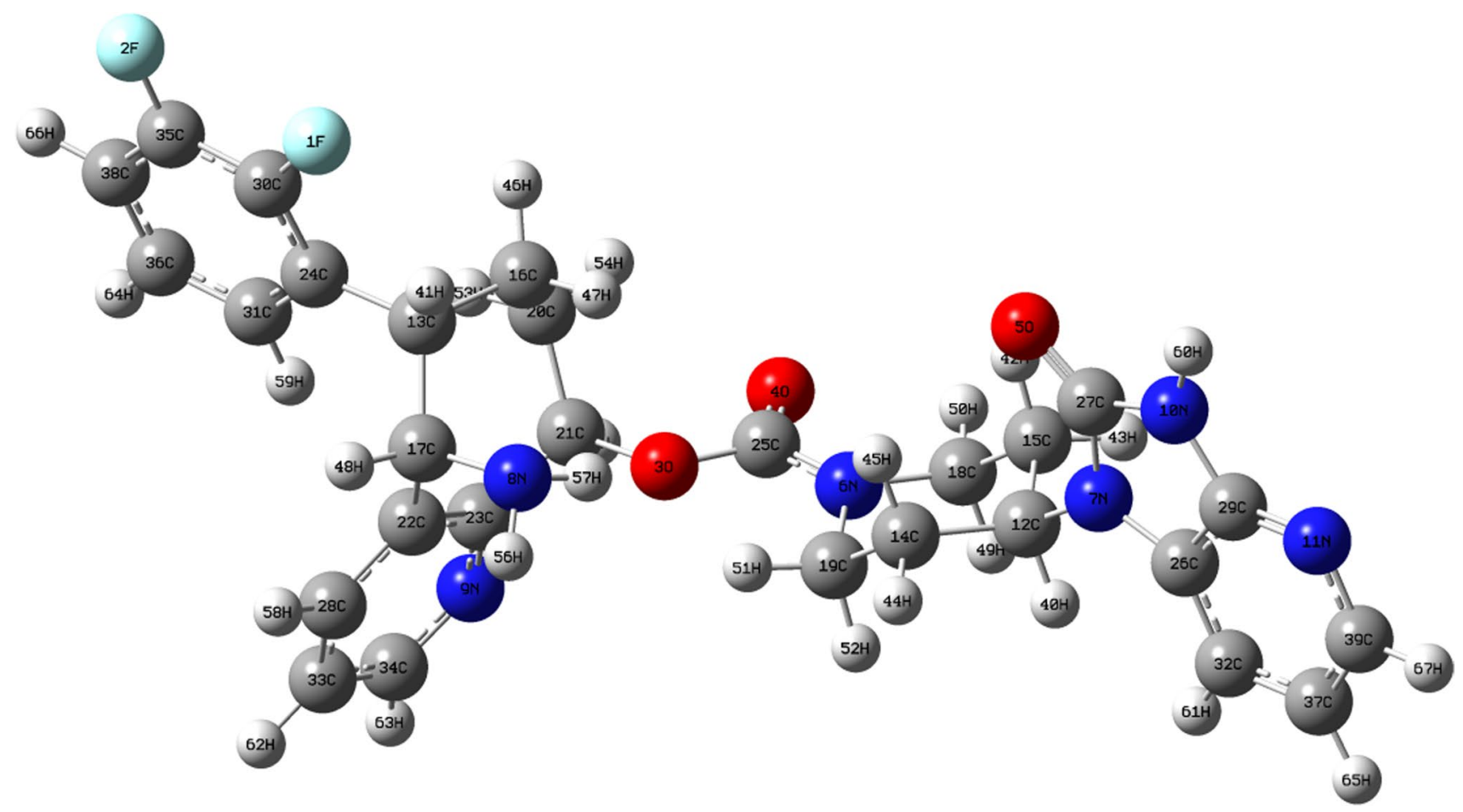

Fig. 1 Optimized structure of rimegepant at B3LYP/6-311G+(2d,p) (blue color indicated nitrogen atoms, red-oxygen, black-carbon, greyhydrogen, and light blue-fluorine) 
Table 1 Frontier molecular orbital properties for rimegepant

\begin{tabular}{ll}
\hline Chemical descriptors & Energy in $\mathrm{eV}$ \\
\hline E(HOMO) & -6.50 \\
E(LUMO) & -1.14 \\
Energy gap $\Delta E$ & 5.36 \\
Ionization energy & 6.50 \\
Electron affinity & 1.14 \\
Global hardness & 2.68 \\
Global softness & 0.37 \\
Chemical potential & -3.82 \\
Electronegativity & 3.82 \\
Electrophilicity index & 2.73 \\
Nucleophilicity index & 0.37 \\
\hline
\end{tabular}

respectively, and the energy gap between them is $5.36 \mathrm{eV}$. The gap is very high that the compound will remain as an organic insulator. The gas-phase ionization energy and electron affinity [49] are 6.5 and $1.14 \mathrm{eV}$ respectively. The global hardness and softness energies for rimegepant are 2.68 and 0.37 respectively. The chemical potential [48], electronegativity [30], electrophilicity index [50-53], and nucleophilicity index [48] for rimegepant are $-3.82,3.82,2.73$, and $0.37 \mathrm{eV}$, which indicates that the molecule is potentially reactive towards biological molecules. The calculated hardness and softness values are 2.68 and 0.37 [54-60].

\section{TD-DFT study for rimegepant in methanol}

Rimegepant molecule structure was optimized by using time-dependent density functional theory RCAMB3LYP as a method, $6-311 \mathrm{G}+(2 \mathrm{~d}, \mathrm{p})$ as a basic set and methanol using as a solvent using the IEFPCM solvation model [35-37]. Figure 2 shows the UV-visible spectrum and Fig. 3 shows the orbitals involved in which the electronic transitions. Figure 2 shows the peak that appears at the wavelength is $260.05 \mathrm{~nm}$ and the oscillator strength is 03082 . Figure 3 shows the important orbitals that participate in an electronic transition. The major peak was due to the transition of electrons from higher occupied molecular orbital (HOMO) to first lower unoccupied molecular orbital (LUMO + 1) which are located at 2H-imidazopyridin-2-one group to cycloheptapyridinamine group respectively with 91 percentage transition contribution.

\section{Nature bonding orbital property for rimegepant}

Intramolecular electron delocalizations due to hyperconjugation are very important for the stabilization of a molecule. Nature bonding orbitals (NBO) can be used as an ideal method for the evaluation of these type of interactions. NBO 3.1 suite [38] associated with the Gaussian09 W program was used to perform these calculations. The orbital occupancy and delocalization energy data helps to analyze

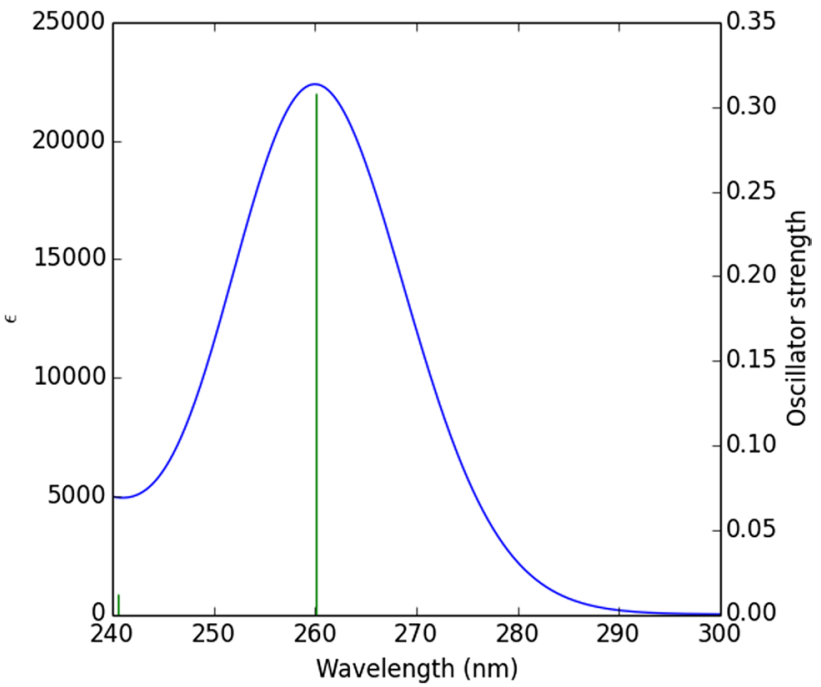

Fig. 2 TD-DFT-simulated UV-visible spectrum of rimegepant

the different electron shifts. Both bonding and anti-bonding orbitals for rimegepant can give details in this part by the transfer of electrons having suitable occupancies, from bonding, lone pairs, and anti-bonding orbitals to anti-bonding orbitals with absorbing some energy.

The bonding electrons transfer from donor bonding orbitals to acceptor anti-bonding orbitals with their occupancies with suitable energies. From $\sigma$ (N9-C23) with the occupancy 1.7135 to $\sigma^{*}(\mathrm{C} 22-\mathrm{C} 28)$ and $\sigma^{*}(\mathrm{C} 33-\mathrm{C} 34)$ with delocalization energies 13.63 and $25.61 \mathrm{kcal} / \mathrm{mol}$ respectively. From $\sigma(\mathrm{N} 11-\mathrm{C} 29)$ with occupancy 1.7448 to $\sigma^{*}$ (C26-C32) and $\sigma^{*}(\mathrm{C} 37-\mathrm{C} 39)$ using the energies are 11.26 and 23.11, from $\sigma(\mathrm{C} 22-\mathrm{C} 28)$ having the occupancy is 1.6318 to $\sigma^{*}$ $(\mathrm{C} 31-\mathrm{C} 36)$ and $\sigma^{*}(\mathrm{C} 33-\mathrm{C} 34)$ with the energies are 26.78 and 18.29 , from $\sigma(\mathrm{C} 24-\mathrm{C} 30)$ with occupancy 1.6625 to $\sigma^{*}(\mathrm{C} 31-\mathrm{C} 36)$ and $\sigma^{*}(\mathrm{C} 35-\mathrm{C} 38)$ taking the energies are 18.45 and 21.66, from $\sigma(\mathrm{C} 26-\mathrm{C} 32)$ has occupancy 1.6810 to $\sigma^{*}(\mathrm{~N} 11-\mathrm{C} 29)$ and $\sigma^{*}(\mathrm{C} 37-\mathrm{C} 39)$ having the energies are 23.52 and 17.08, from $\sigma(\mathrm{C} 31-\mathrm{C} 36)$ with occupancy 1.6789 to $\sigma^{*}(\mathrm{C} 24-\mathrm{C} 30)$ and $\sigma^{*}(\mathrm{C} 35-\mathrm{C} 38)$ having the energies are 20.82 and 19.77, from $\sigma$ (C33-C34) with occupancy 1.6309 to $\sigma^{*}(\mathrm{~N} 9-\mathrm{C} 23)$ and $\sigma^{*}(\mathrm{C} 22-\mathrm{C} 28)$ by taking the energies are 18.06 and 21.43 , from $\sigma(\mathrm{C} 35-\mathrm{C} 38)$ with the occupancy is 1.6793 to $\sigma^{*}(\mathrm{C} 24-\mathrm{C} 30)$ and $\sigma^{*}(\mathrm{C} 31-\mathrm{C} 36)$ having the energies are 19.09 and 18.95, and from $\sigma(\mathrm{C} 37-\mathrm{C} 39)$ has occupancy 1.6902 to $\sigma^{*}(\mathrm{~N} 11-\mathrm{C} 29)$ and $\sigma^{*}(\mathrm{C} 26-\mathrm{C} 32)$ by with energy are 14.65 and $19.85 \mathrm{kcal} / \mathrm{mol}$.

The lone pairs of electrons transfer from donor bonding orbitals to acceptor anti-bonding and anti-Rydberg orbital by with energy with suitable occupancies. From lone-pair electrons in bonding orbitals are $\mathrm{n}(\mathrm{F} 1), \mathrm{n}(\mathrm{F} 2)$, $\mathrm{n}(\mathrm{O} 3), \mathrm{n}(\mathrm{O} 4), \mathrm{n}(\mathrm{O} 4)$, and $\mathrm{n}(\mathrm{O} 5)$ having the occupancies are $1.9276,1.9264,1.8338,1.8332,1.9735$, and 1.9745 to anti-bonding and anti-Rydberg orbitals are $\sigma^{*}(\mathrm{C} 24-\mathrm{C} 30)$, 

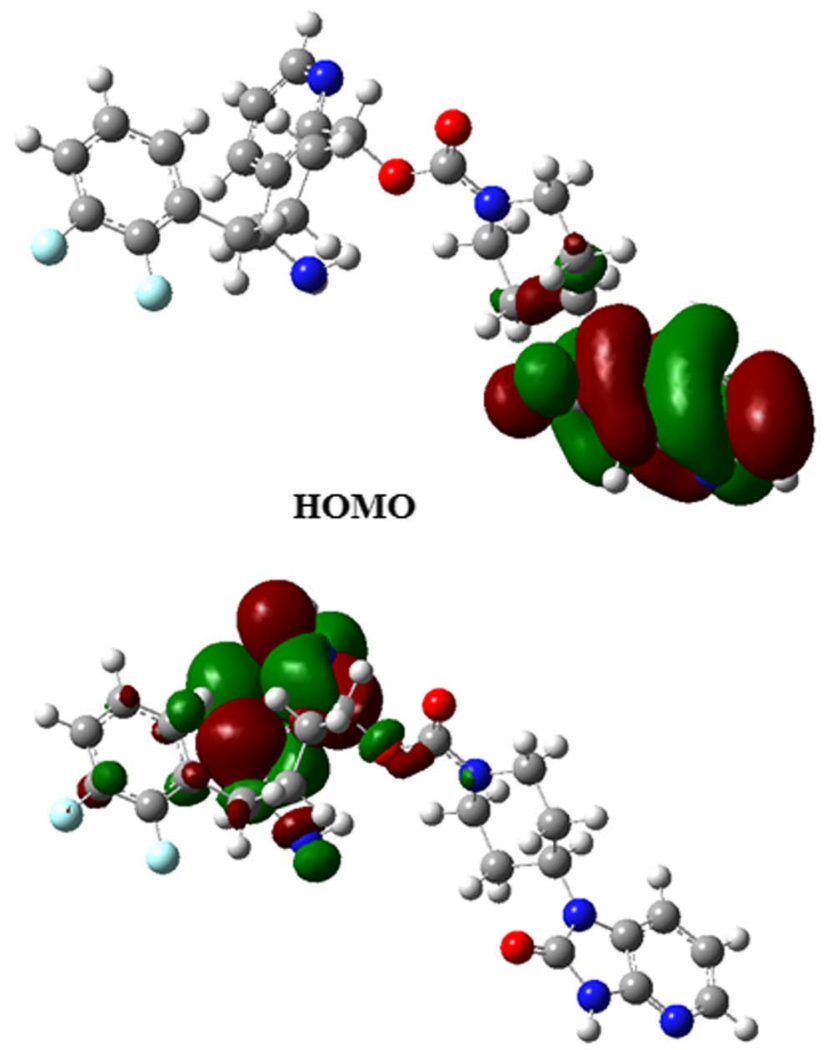

LUMO+1

Fig. 3 Representative FMOs of rimegepant

$\sigma^{*}(\mathrm{C} 35-\mathrm{C} 38), \sigma^{*}(\mathrm{O} 4-\mathrm{C} 25), \sigma^{*}(\mathrm{~N} 6-\mathrm{C} 25), \mathrm{RY}^{*}(\mathrm{C} 25)$, and $\mathrm{RY}^{*}(\mathrm{C} 27)$ by taking the energies are $17.45,18.34$, $14.89,15.32,15.87$, and 16.93. From n (O5) has occupancy 1.8352 to $\sigma^{*}(\mathrm{~N} 7-\mathrm{C} 27)$ and $\sigma^{*}(\mathrm{~N} 10-\mathrm{C} 27)$ having the energies are 28.02 and 27.14, from n (N6) having occupancy 1.7085 to $\sigma^{*}(\mathrm{O} 4-\mathrm{C} 25)$ having the energy is $15.77 \mathrm{kcal} / \mathrm{mol}$, from $\mathrm{n}(\mathrm{N} 7)$ with the occupancy is 1.6436 to $\sigma^{*}(\mathrm{O} 5-\mathrm{C} 27)$ and $\sigma^{*}(\mathrm{C} 26-\mathrm{C} 32)$ having the energies are 58.01 and 41.66 , from $n(\mathrm{~N} 9)$ has occupancy 1.9177 to

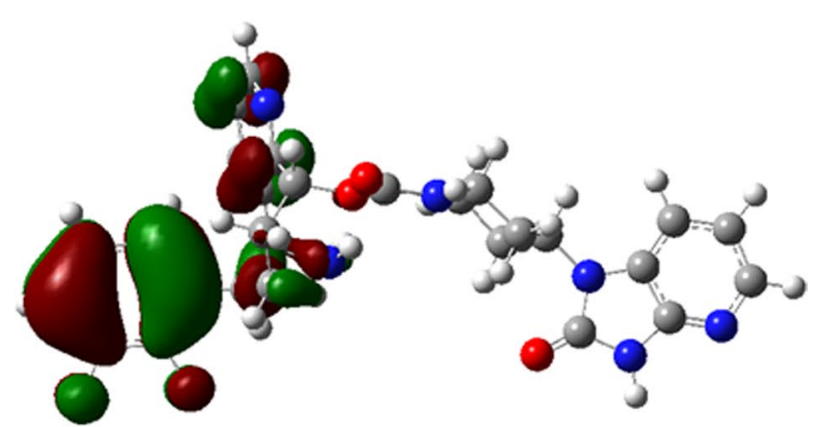

HOMO-5

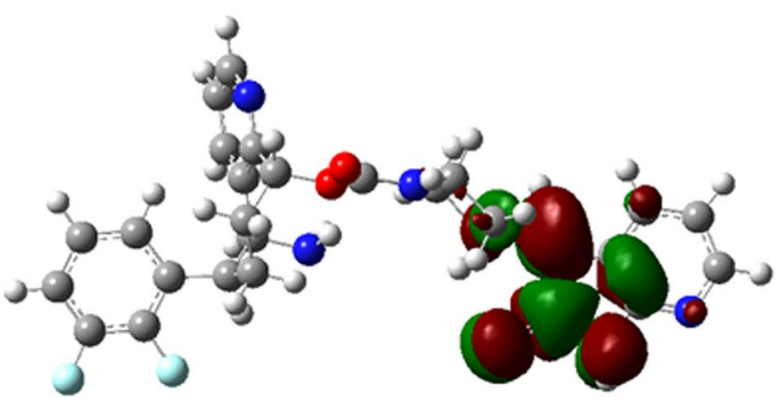

LUMO+8

Fig. 4 Molecular electrostatic potential map of rimegepant depicting reactivity centers

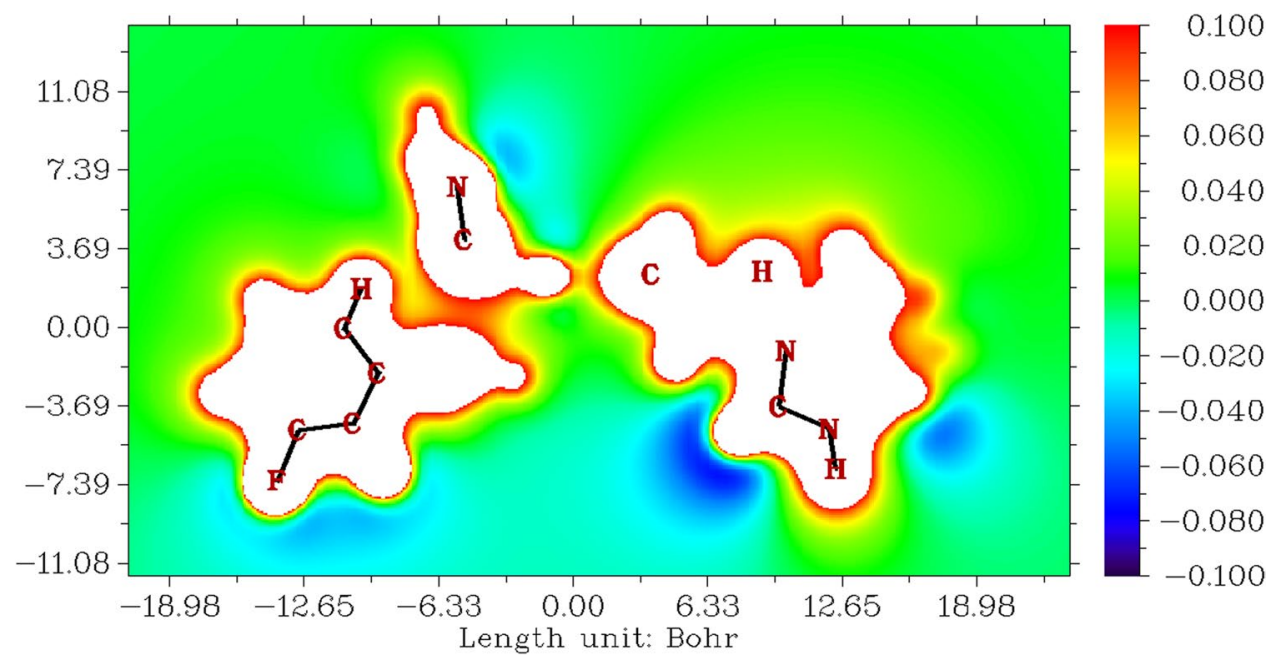

$\sigma^{*}(\mathrm{C} 22-\mathrm{C} 23)$ and $\sigma^{*}(\mathrm{C} 33-\mathrm{C} 34)$ having the energies are 11.22 and 9.61, from n (N10) with occupancy 1.6560 to $\sigma^{*}(\mathrm{O} 5-\mathrm{C} 27)$ and $\sigma^{*}(\mathrm{~N} 11-\mathrm{C} 29)$ having the energies are 57.19 and 47.23, and from n (N11) has occupancy 1.9097 to $\sigma^{*}(\mathrm{C} 26-\mathrm{C} 29)$ and $\sigma^{*}(\mathrm{C} 37-\mathrm{C} 39)$ by with energy are 12.31 and $8.78 \mathrm{kcal} / \mathrm{mol}$.

The electrons transfer from anti-bonding orbitals to other anti-bonding orbitals by with the occupancies and with energy. From $\sigma^{*}(\mathrm{O} 4-\mathrm{C} 25), \sigma^{*}(\mathrm{O} 4-\mathrm{C} 25)$ and $\sigma^{*}(\mathrm{C} 35-\mathrm{C} 38)$ 
Fig. 5 Average localized ionization energy map rimegepant representing the reactivity centers

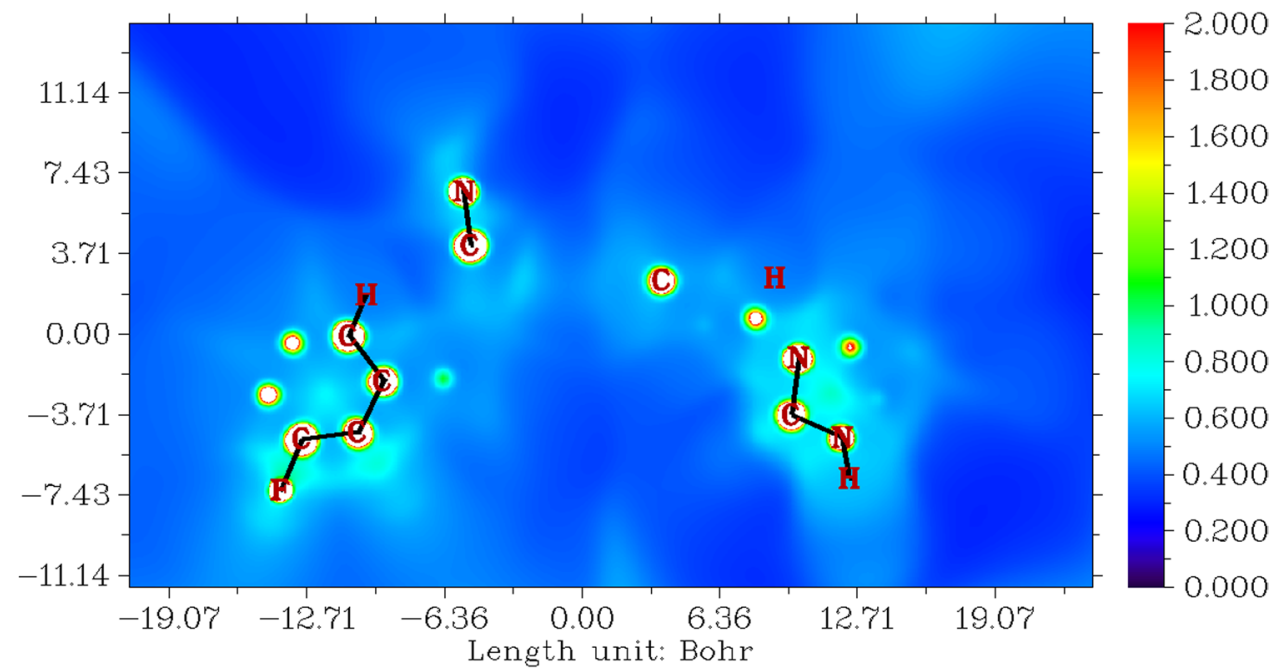

having the occupancies are $0.1817,0.2248$, and 0.3857 to $\sigma^{*}$ $(\mathrm{O} 3-\mathrm{C} 25), \sigma^{*}(\mathrm{O} 4-\mathrm{C} 25)$ and $\sigma^{*}(\mathrm{C} 31-\mathrm{C} 36)$ by taking the energies are 21.19, 247.54, and 232.22, from $\sigma^{*}$ (N9-C23) has occupancy is 0.3877 to $\sigma^{*}(\mathrm{C} 22-\mathrm{C} 28)$ and $\sigma^{*}(\mathrm{C} 33-\mathrm{C} 34)$ having the energies are 200.59 and 210.34 , from $\sigma^{*}$ (N11-C29) with occupancy 0.4408 to $\sigma^{*}$ (C26-C32) and $\sigma^{*}$ (C37-C39) having the energies are 268.80 and $137.72 \mathrm{kcal} / \mathrm{mol}$.

\section{Molecular electrostatic potentials of rimegepant}

Molecular electrostatic potentials (MEP) explain the reaction sites that appear in a molecule [39-41].
Figure 4 shows the reaction sites of rimegepant molecule, within \pm 18.98 Bohr $^{3}$ from the numerical value from -1.000 to 0.100 , and from blue to red in color. The blue color on primary amine nitrogen and nitrogen in cycloheptapyridinamine, carbonyl oxygen in piperidine-1-carboxylate, and 2H-imidazopyridine-2-one groups are electron-rich sites so electrophiles can easily attack these sites. The red color is for all the carbon having protons in $2 \mathrm{H}$-imidazopyridine-2-one and piperidine-1-carboxylate, and carbon having protons and primary amine protons in cycloheptapyridinamine groups; these are electron-poor sites so nucleophiles can easily attack these sites.
Fig. 6 Non-covalent interactions present in rimegepant

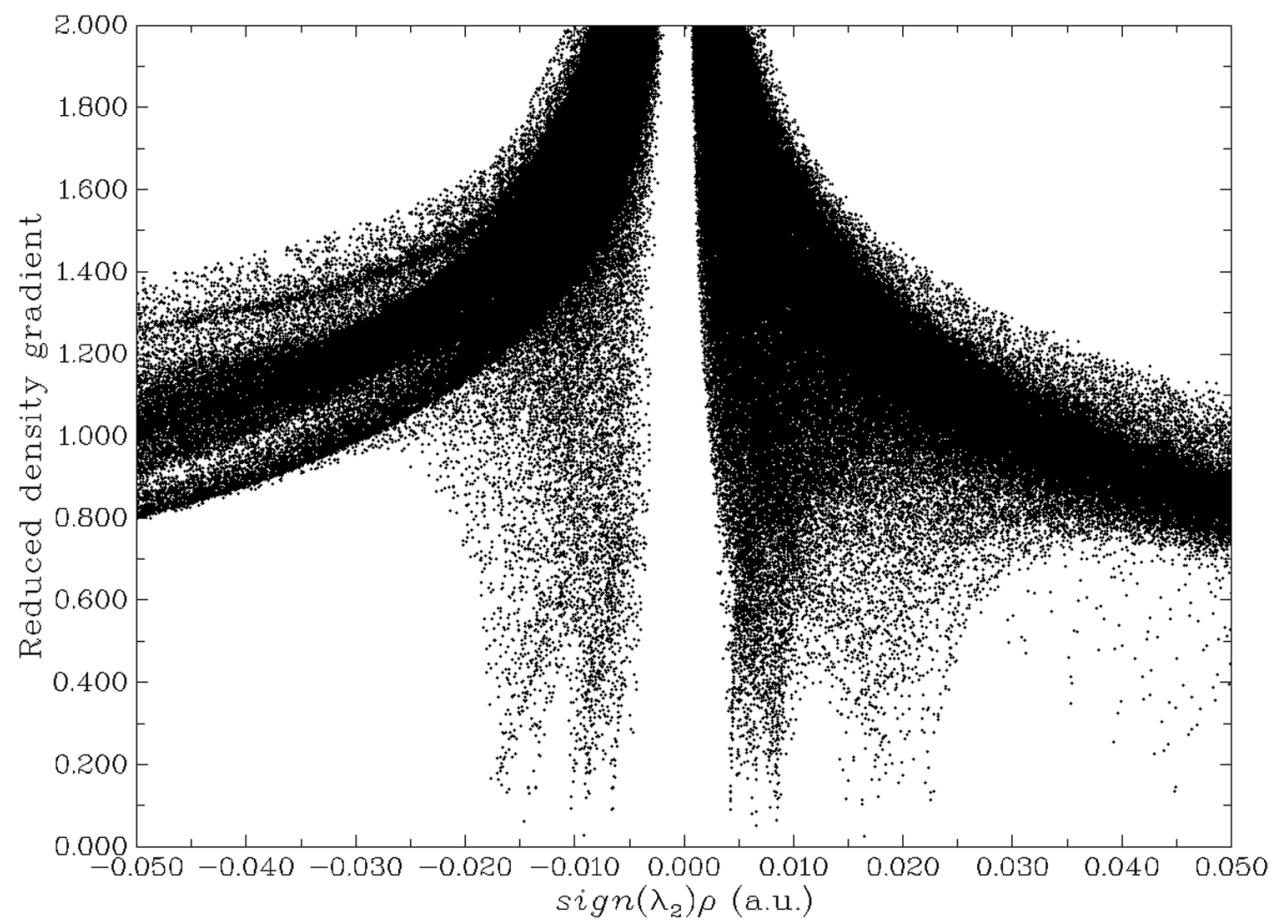


Fig. 7 Comparison plot of the proton affinities $(\mathrm{kcal} / \mathrm{mol})$ corresponding to the six different nitrogen atoms of rimegepant molecule (B3LYP/6$311 \mathrm{G}+(2 \mathrm{~d}, \mathrm{p}))$

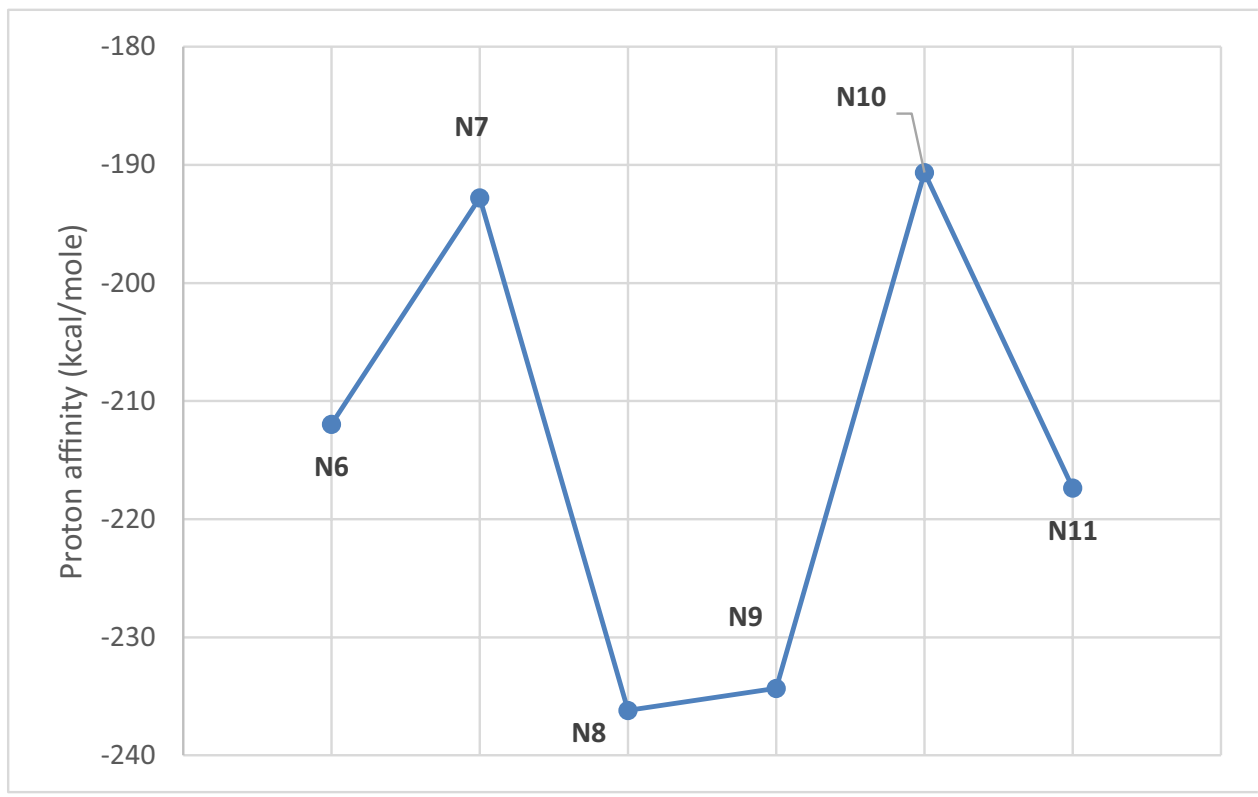

\section{Average localized ionization energy property of rimegepant}

Rimegepant molecule was optimized by using density functional theory DFT-B3LYP as a method, and $6-311 \mathrm{G}+(2 \mathrm{~d}, \mathrm{p})$ as a basis set. The average localized ionization energy (ALIE) can explain the resonance structure of the molecule, which also explains saturated and unsaturated bonds in the molecule, and its stability. Figure 5 shows the reaction sites of rimegepant molecule, within $\pm 19.07 \mathrm{Bohr}^{3}$ from the numerical value from 0.000 to 2.000 , and from blue to red in color [42-44]. The blush-green color indicates the unsaturated or moving or delocalized electrons in rimegepant molecule, in 2H-imidazopyridine-2-one group, on amine nitrogen to carbon in cycloheptapyrinamine group, and in ring and fluorines to carbons in 1,2-difluorophenyl group; these areas are unsaturated or delocalized electrons sites so addition reactions can occur in these sites. The blue color is on all the protons in piperidine-1-carboxylate, cycloheptapyridinamide, and adjacent carbon in $2 \mathrm{H}$-imidazopyridin2-one groups; these sites are saturated single bond sites so substitution reactions can occur in these sites.

\section{Non-covalent interactions of rimegepant}

Rimegepant molecule structure was optimized by using density functional theory DFT-B3LYP as a method, and $6-311 \mathrm{G}+(2 \mathrm{~d}, \mathrm{p})$ as a basic set. The non-covalent interaction (NCI) property explains the non-covalent interaction but few types of bond attractions appear within the molecule, which are hydrogen, van der Waals, and steric type of forces [45-48]. Figure 6 shows the non-covalent bond within rimegepant molecule, a graph-plotted energy against a reduced density gradient. The hydrogen bond appears the energy from -0.198 to -0.006 a.u. from fluorines to protons in the same 1,2-difluorophenyl and cycloheptapyridine groups. The van der Waals force of attractions are from carbonyl oxygen in $2 \mathrm{H}$-imidazopyridin-2-one group to protons in piperidine-1-carboxylate group, and from oxygen in piperidine-1-carboxylate group to protons in the same group and protons in cycloheptapyridinamine group. The steric force of attractions is shown from 1,2-difluorophenyl group to cycloheptapyridinamine group, and from piperidine-1-carboxylate to $2 \mathrm{H}$-imidazopyridin-2-one group.

\section{Proton affinity and regioselectivity of protonation process of rimegepant}

The rimegepant molecule, with its six nitrogen atoms, shows very high proton affinity. Due to the differences in the nature of the electronic environment, the proton affinities corresponding to the nitrogen atoms are different for different nitrogen atoms. Looking at the structure of the molecule, it can be seen that there is one nitrogen atom (N8) in the form of a free amine group attached to the cycloheptane ring, while there are two nitrogen atoms (N9 and N11) in the two pyridine rings. Again, one nitrogen atom (N6) can be observed as a constituent of the piperidine ring, while the imidazolone ring of the molecule contains two more nitrogen atoms (N7 and N10). An attempt was made to study the difference in proton affinity of the systems by estimating the enthalpy of protonation using the equation:

$\Delta H_{\text {protonaffinity }}=H_{\text {protonatedsystem }}-\left(H_{\text {remegepant }}+H_{\text {proton }}\right)$ 


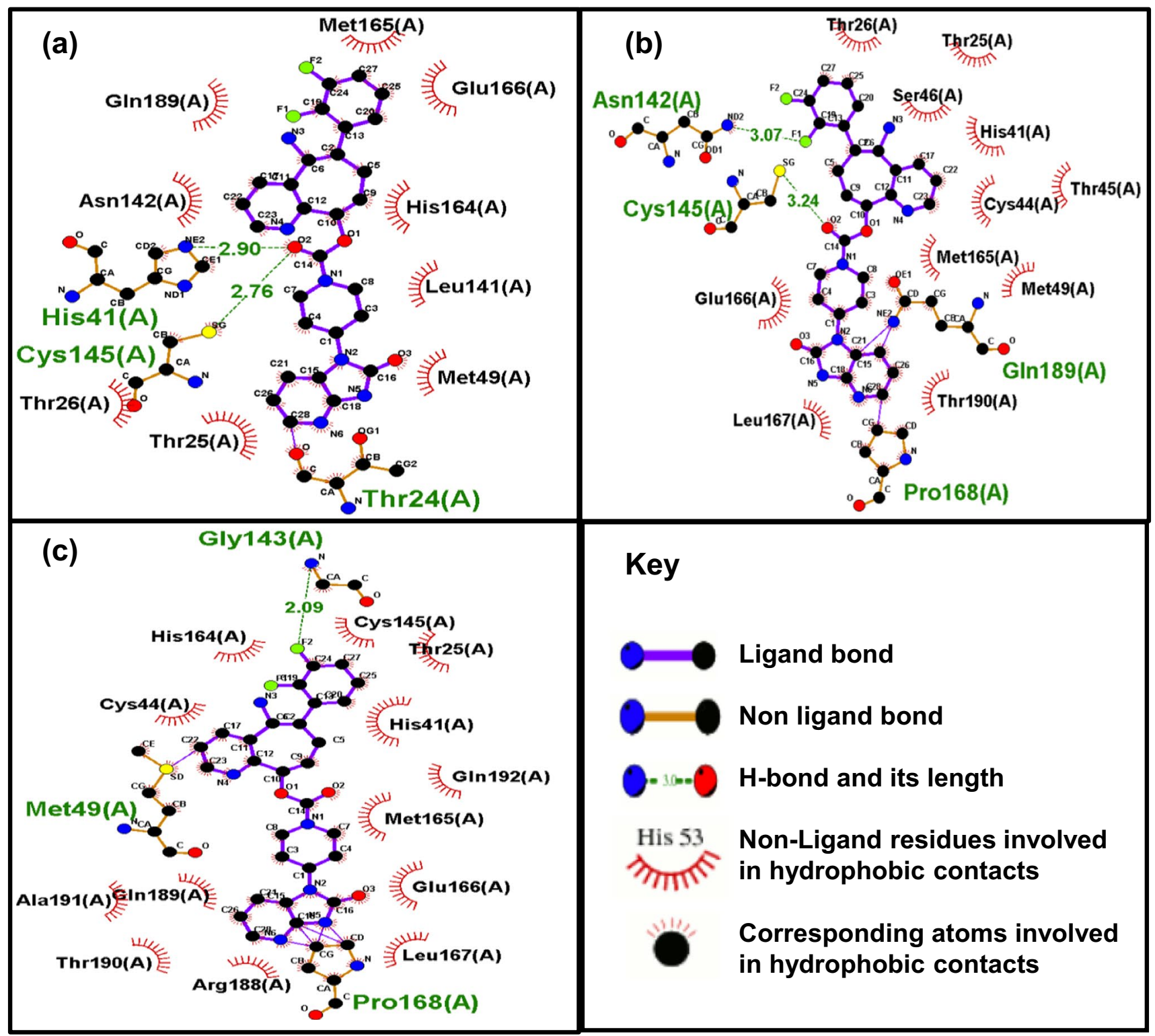

Fig. 8 Protein-ligand interactions between rimegepant and a 6LU7, b 6M03, and $\mathbf{c} 6 \mathrm{~W} 63$ proteins as depicted in LigPlot. The bond lengths presented are in angstroms $(\AA)$

Figure 7 graphically represents and compares all these six proton affinities.

Figure 7 indicates that N8, i.e., the nitrogen atom of the free amine group, has the greatest proton affinity, followed by N9, i.e., the nitrogen atom of the pyridine ring, which is fused with the cycloheptane ring. Then comes $\mathrm{N} 11$, i.e., the nitrogen atom of the other pyridine ring, which is fused with the imidazolone ring, followed by N6, i.e., the nitrogen atom of the piperidine ring. $\mathrm{N} 7$ and $\mathrm{N} 10$, that are presented in the imidazolone ring, show comparatively less proton affinities. So, the order of the proton affinities of the six nitrogen atoms of the molecule becomes $\mathrm{N} 8>\mathrm{N} 9>\mathrm{N} 11>\mathrm{N} 6>\mathrm{N} 7>\mathrm{N} 10$.
$\mathrm{N} 8$ is the part of an isolated and independent amine group. It is the only nitrogen atom present in the rimegepant molecule that is not a part of any ring. So, the availability of the lone pair of electrons on it is not reduced by any electron withdrawing effect. This makes N8 have the highest proton affinity among the nitrogen atoms of the molecule. Then comes the nitrogen atoms of the pyridine rings N9 and $\mathrm{N} 11$ as the corresponding lone pairs of electrons do not participate in the resonance of the pyridine rings. The proton affinity of $\mathrm{N} 9$ is greater than that of N11, probably because, in the case of the latter, the corresponding pyridine ring is fused with an imidazolone ring, which pulls the electron cloud of the pyridine ring and makes the lone pair of 
Fig. 9 RMSD of the ligand (rimegepant) with respect to $\mathbf{a}$ PDB: 6LU7, b PDB: 6M03, and c PDB: 6 W63 over a timeframe of $400 \mathrm{~ns}$. The RMSD values for the protein models were computed using alpha carbons
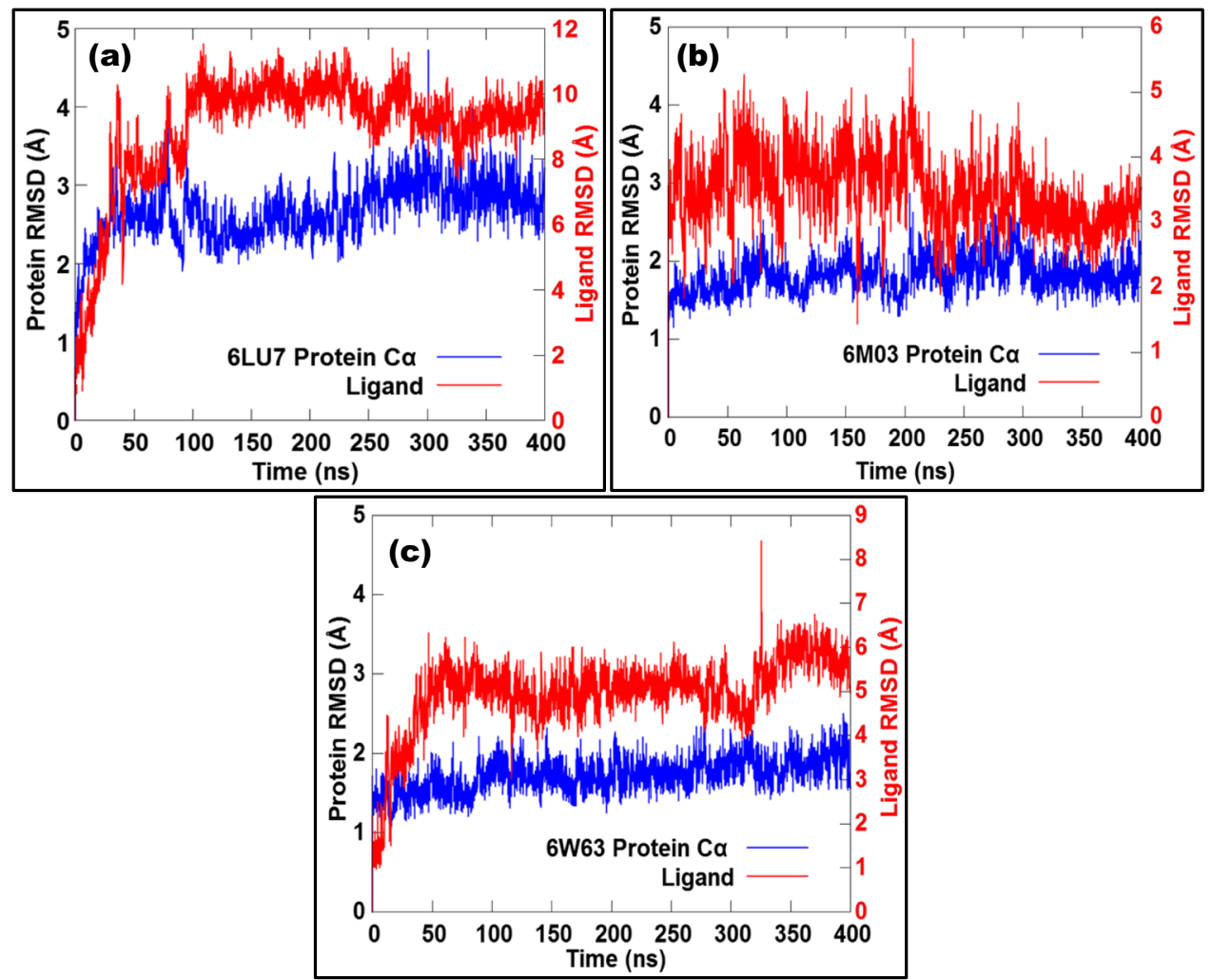

electrons of N11 comparative less donatable than N7. The proton affinity of N6 is further less because of the conjugation of N6 with the attached-COOR group that reduces the availability of the lone pair of electrons on N6. The proton affinities of N7 and N10 are comparatively less than that of the rest of the nitrogen atoms, as these nitrogen atoms enjoy a cross conjugation with a carbonyl group. Protonation at any one of the nitrogen atoms between N7 and N11 is possible only at the cost of sacrificing this stabilizing cross conjugation. The proton affinity of N7 is slightly more than that of N10 probably as the former is attached to the piperidine ring that slightly increases the availability of the lone pair of electrons on it by $+\mathrm{I}$ effect.

\section{Molecular docking for rimegepant with SARS-CoV-2 proteins}

As the world is facing the severe pandemic COVID, we thought of assessing rimegepant's activity towards the known COVID proteins. We used molecular docking procedures for this study as mentioned in the methods section. This study gives biological activity information about the

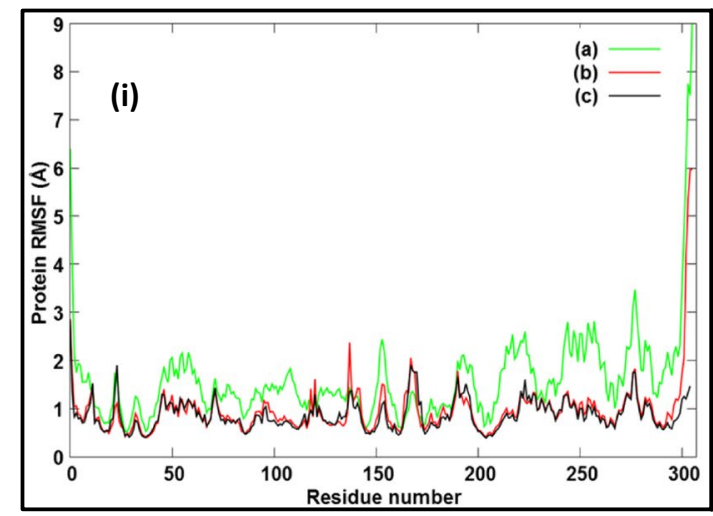

Fig. 10 (i) Docked protein root mean square fluctuations (RMSF) of alpha carbon atoms. (a) 6LU7, (b) 6M03, and (c) 6W63. N- and $\mathrm{C}$-terminals show most fluctuations on all models as expected while

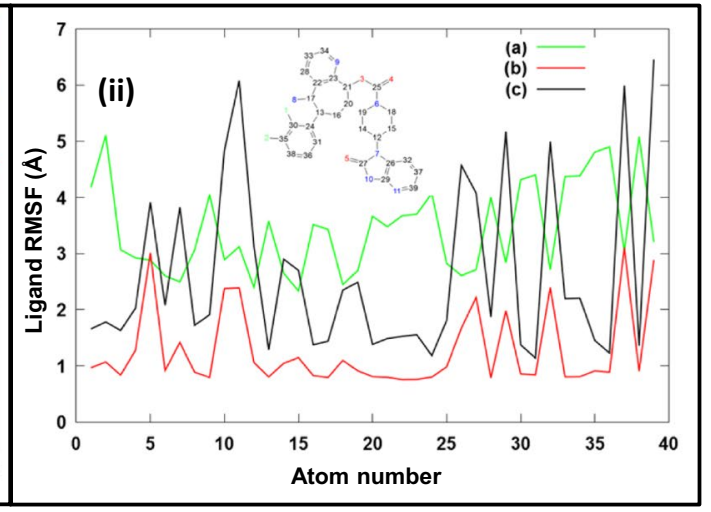

all other resides are stable. Plot (ii) depicts docked rimegepant RMSF on (a) PDB6LU7, (b) 6M03, and (c) 6W63. Herein, it can be observed that the ligand is more stable when complexed with 6LU7 
Table 2 MMGBSA* results of rimegepant on the selected PDB models

\begin{tabular}{llllllll}
\hline PDB ID & $\Delta G$ & $\Delta G_{\text {Coulomb }}$ & $\Delta G_{\text {ELE }}$ & $\Delta G_{\text {Covalent }}$ & $\Delta G_{\text {Hbond }}$ & $\Delta G_{\text {Solv }}$ & $\Delta G_{\mathrm{VdW}}$ \\
\hline 6LU7 & -67.13 & -31.99 & -18.65 & 1.51 & -1.65 & 30.54 & -46.89 \\
6M03 & -65.30 & -46.86 & -17.52 & 3.22 & -0.84 & 51.28 & -54.58 \\
6W63 & -52.02 & -29.49 & -18.79 & 3.89 & -0.11 & 39.51 & -47.03 \\
\hline
\end{tabular}

*All values are reported in $\mathrm{kcal} / \mathrm{mol}$. type of interactions between rimegepant and SARS-CoV-2 proteins (PDB IDs: 6LU7 [49], 6M03, and 6W63 residues.
Table S1 shows the docking results between rimegepant and SARS-CoV-2 proteins. The free energy of docking was
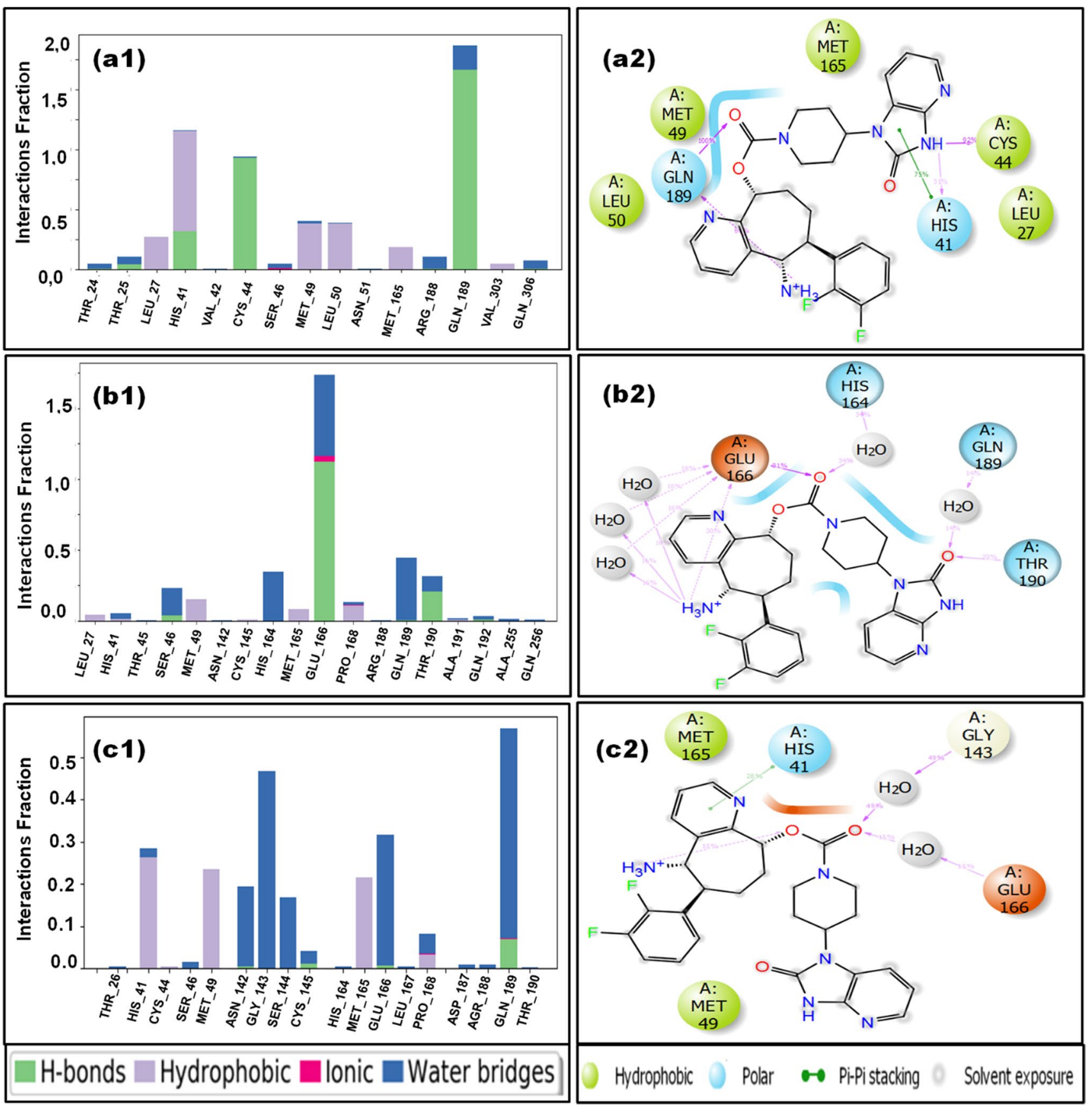

Fig. 11 Protein-ligand interactions (left) and ligand atom interactions (right) with the respective protein receptor residues, (a) 6LU7, (b) 6M03, and (c) 6W63 all docked with rimegepant (ligand) 
found to be $-9.2,-8.3$, and $-9.5 \mathrm{kcal} / \mathrm{mol}$ respectively for the 6LU7, 6M03, and 6W63 systems. The free energy values are very high and hence we decided to investigate further.

The score values 5740, 5764, and 6002 are rimegepant with SARS-CoV-2 proteins 6LU7, 6M03, and 6W63, respectively, surface areas are $667.40,666.10$, and $711.80 \AA^{2}$ for rimegepant with SARS-CoV-2 proteins 6LU7, 6M03, and $6 \mathrm{~W} 63$, respectively, and minimum atomic contact energies are $-280.28,-265.46$, and -327.41 for rimegepant with SARS-CoV-2 proteins are 6LU7, 6M03, and 6W63 respectively. Table $\mathrm{S} 2$ represents different interactions between rimegepant and the proteins (6LU7, 6M03, and 6W63) while Fig. 8 gives a pictorial representation of interactions between drug and aminoacid residues [40, 48, 50-53]. Table $\mathrm{S} 3$ shows the non-bond interactions between rimegepant with SARS-CoV-2 proteins (6LU7, 6M03, and 6W63).

\section{Molecular dynamic study for rimegepant}

Root mean standard deviation (RMSD) fluctuations were used to assess if the protein-ligand had stabilized during the production stage. The results for the simulations of docked complexes are presented in Fig. 9. For all the three protein-ligand complexes, equilibrium was attained at about 200 ns showing protein RMSD fluctuations of less than $2 \AA$. Close examination of all the three proteins (COVID-19 main protease synthetic construct with ID 6LU7, COVID-19 main protease apro form with ID 6M03, and main protease natural with PDB 6W63) showed no distortion of either the protein or docked ligand. Further assessment with protein root mean square fluctuations (RMSF) also confirmed that all the proteins were stable in their states. Examining the RMSF (Fig. 10), the $N$ - and $C$-terminals fluctuated more than other residues as expected. The other amino acids showed average fluctuations of less than $2.4 \AA$ for docked 6LU7 and 6M03 while 6 W63 had average fluctuations less than $2 \AA$. These findings demonstrate that all the three protein models were stable when docked with rimegepant over an MD timescale of $400 \mathrm{~ns}$. Although there was a surge in rimegepant (6W63) RMSD at around $325 \mathrm{~ns}$ (Fig. 8c), inspection of the trajectory revealed that the imidazolium side chain on the ligand was adjusting to a more stable position within the binding pocket [80-84].

Average protein-ligand interactions were computed from $250 \mathrm{~ns}$ to the last frame, the region in which all the complexes had equilibrated. The results are outlined in Fig. 11 below.

On all models, hydrophobic interactions were found to be the primary forces for rimegepant binding onto the receptors. Residues such as HIS, MET, CYS, and LEU were among the major contributors to hydrophobic interactions as illustrated in Fig. 11. For 6LU7, and 6M03, hydrophobic interactions between the ligand and protein residues HIS and MET were observed to occur more than $50 \%$ of the stipulated MD timeframe. GLN contributed significantly via $\mathrm{H}$-bond interactions with rimegepant for than $100 \%$ of the MD production time particularly with 6LU7 and 6M03. Residues such as HIS, CYS, and THR also interacted with the ligand for at least $30 \%$ of the MD timeframe. Although similar interactions were noted on the receptor on $6 \mathrm{~W} 63$, the residues involved were different. For example, with 6LU7 and 6M03, HIS offered both hydrophobic and H-bond interactions; whereas in 6W63, only hydrophobic interactions were observed, Furthermore, instead of direct H-bonding with GLN, water bridges appeared dominant and essential for ligand binding on 6W63. In addition to hydrophobic interactions, water bridges, predominantly with glutamine, also play a major role towards the binding of rimegepant to all the protein models. Lastly, pi-pi interactions, predominantly with histidine (HIS41), appeared to stabilize the docked complexes during the stipulated timeframe.

Further investigation of binding strength on different proteins was performed using molecular mechanics generalized born surface area (MM/GBSA) calculations to predict the estimate binding free energies of rimegepant on the selected protein models. The MMGBSA module estimate binding free energy $\left(\Delta G_{\text {bind }}\right)$ as a difference between the docked complex $\left(\Delta G_{\text {complex }}\right)$ and the free receptor $\left(\Delta G_{\text {receptor }}\right)$ and ligand $\left(\Delta G_{\text {ligand }}\right)$ as shown below.

$\Delta G_{\text {bind }}=\Delta G_{\text {complex }}-\Delta G_{\text {receptor }}-\Delta G_{\text {ligand }}$

For the individual components, the change in free energy for binding may be expressed as:

$\Delta G_{\text {bind }}=\Delta H-T \Delta S \approx \Delta E_{\text {contributions }}+\Delta G_{\text {solv }}-T \Delta S$

[Ref https://doi.org/10.3390/molecules25173852, https://doi.org/10.3390/molecules25184183].where $\Delta E_{\text {contributions }}$ refers to total energy contributions emanating from forces such as Coulombic, $\mathrm{H}$-bond, covalent, and Van der Waals interactions. In this work, $\Delta G_{\text {ELE }}$ (Table 2) represents combined electrostatics from lipophilic and packing contributions. The rest of the contributions such as Coulombic, H-bond, covalent, and Van der Waals interactions were listed individually. MM/GBSA energies were calculated from frame 2500 to frame 4000 where the system had equilibrated. The results are as presented in Table 2.

Although favorable binding is shown on all models, binding of rimegepant to PDB model 6LU7 appeared to be the most favored. In all models, van der Waals forces were the major contributors towards the binding energy. This is somewhat in agreement with our docking results where rimegepant and 6LU7 have higher full fitness, inter full fitness, solvent full fitness and better $\Delta G$ complex solvent polar than other two proteins. 


\section{Conclusions}

The results from frontier molecular analysis chemical descriptors of rimegepant were analyzed. NBO studies revealed the intensity of various intramolecular interactions. TD-DFT study of rimegepant explained the UV-visible spectral property, and major and minor contributions orbitals. The various wavefunction studies are MESP, ALIE, and NCI data that helped to predict the more than one reactivity and active site such as 1,2 difluorophenyl, cycloheptapyridinamine, piperidine-1-carboxylate, and $2 \mathrm{H}$-imidazopyridin-2-one in rimegepant. Docking studies explained the $\Delta G$, scores, minimum atomic contact energies, and different types of interactions between rimegepant and SARS-CoV-2 proteins. Time-dependent behaviors of docked complexes were investigated using molecular dynamics simulations over a time frame of $400 \mathrm{~ns}$. Herein, intermolecular forces such as water bridges, $\pi-\pi$, and hydrophobic interactions were found to be the major contributors for ligand binding to receptor pocket. Estimate binding free energies using MMGBSA further demonstrated that rimegepant binding to the selected protein models (6LU7, 6M03, and 6W63) is favorable on all models with PDB 6LU7 being the most favored. It can be concluded that this compound may be investigated further for a potential medicine to act against the SARS-CoV-2.

Supplementary Information The online version contains supplementary material available at https://doi.org/10.1007/s00894-021-04885-z.

Acknowledgements The authors would like to acknowledge the Faculty of Science: University of Johannesburg: Centre for Nanomaterials Science Research, Department of Chemical Sciences and the National Research Foundation (TTK170405225933) South Africa. The authors are also thankful to the Centre for High Performance Computing (CHPC) for computational resources.

Author contribution T. Pooventhiran: DFT studies, manuscript writing. Ephraim Felix Marondedze: Molecular dynamics study.

Penny Poomani Govender: MD study supervision and writing, funding for MD studies.

Utsab Bhattacharyya: Proton affinity studies, manuscript draft correction.

D. Jagadeeswara Rao: Docking studies.

Elham S. Aazam: Method development and standardization.

Jinesh M. Kuthanapillil: Manuscript preparation, data analysis.

Tomlal Jose E: Manuscript preparation, data curation and validation.

Renjith Thomas: Conceiving of the problem, supervision, software, method development, manuscript draft.

Data availability Additional materials are available in the Supplementary Information Files.

Code availability We have not developed any new codes. Existing codes have been used and they are properly cited.

\section{Declarations}

Conflict of interest The authors declare no competing interests.

\section{References}

1. Russo AF (2019) CGRP-Based migraine therapeutics: how might they work, why so safe, and what next? ACS Pharmacol Transl Sci 2:2-8. https://doi.org/10.1021/acsptsci.8b00036

2. Croop R, Goadsby PJ, Stock DA, Conway CM, Forshaw M, Stock EG, Coric V, Lipton RB (2019) Efficacy, safety, and tolerability of rimegepant orally disintegrating tablet for the acute treatment of migraine: a randomised, phase 3 , double-blind, placebo-controlled trial. Lancet. 394:737-745. https://doi.org/10.1016/S01406736(19)31606-X

3. Sparrow AM, Searles JW (2019) The market for migraine drugs. Nat Rev Drug Discov 18:333-334. https://doi.org/10.1038/ d41573-018-00014-3

4. Gingell JJ, Rees TA, Hendrikse ER, Siow A, Rennison D, Scotter J, Harris PWR, Brimble MA, Walker CS, Hay DL (2020) Distinct Patterns of internalization of different calcitonin gene-related peptide receptors. ACS Pharmacol. Transl. Sci. 3:296-304. https:// doi.org/10.1021/acsptsci.9b00089

5. Hendrikse ER, Liew LP, Bower RL, Bonnet M, Jamaluddin MA, Prodan N, Richards KD, Walker CS, Pairaudeau G, Smith DM, Rujan R-M, Sudra R, Reynolds CA, Booe JM, Pioszak AA, Flanagan JU, Hay MP, Hay DL (2020) Identification of small-molecule positive modulators of calcitonin-like receptor-based receptors. ACS Pharmacol. Transl. Sci. 3:305-320. https://doi.org/10.1021/ acsptsci.9b00108

6. Olesen J, Ashina M (2019) Calcitonin gene-related peptide beyond migraine prophylaxis. Nat. Rev. Neurol. 15:562-564. https://doi.org/10.1038/s41582-019-0258-1

7. Luo G, Chen L, Conway CM, Kostich W, Macor JE, Dubowchik GM (2015) Asymmetric synthesis of heterocyclic analogues of a CGRP receptor antagonist for treating migraine. Org. Lett. 17:5982-5985. https://doi.org/10.1021/acs.orglett.5b02921

8. Scott LJ (2020) Rimegepant: first approval. Drugs. 80:741-746. https://doi.org/10.1007/s40265-020-01301-3

9. Zhou P, Yang X-L, Wang X-G, Hu B, Zhang L, Zhang W, Si H-R, Zhu Y, Li B, Huang C-L, Chen H-D, Chen J, Luo Y, Guo H, Jiang R-D, Liu M-Q, Chen Y, Shen X-R, Wang X, Zheng X-S, Zhao K, Chen Q-J, Deng F, Liu L-L, Yan B, Zhan F-X, Wang Y-Y, Xiao G-F, Shi Z-L (2020) A pneumonia outbreak associated with a new coronavirus of probable bat origin. Nature 579:270-273. https:// doi.org/10.1038/s41586-020-2012-7

10. Lake MA (2020) What we know so far: COVID-19 current clinical knowledge and research. Clin. Med. 20:124-127. https://doi.org/ 10.7861/clinmed.2019-coron

11. Kaur SP, Gupta V (2020) COVID-19 Vaccine: a comprehensive status report. Virus Res. 288:198114. https://doi.org/10.1016/j. virusres.2020.198114

12. Ong E, Wong MU, Huffman A, He Y (2020) COVID-19 coronavirus vaccine design using reverse vaccinology and machine learning. BioRxiv Prepr Serv Biol. https://doi.org/10.1101/2020. 03.20.000141

13. Forni G, Mantovani A, Forni G, Mantovani A, Moretta L, Rappuoli R, Rezza G, Bagnasco A, Barsacchi G, Bussolati G, Cacciari M, Cappuccinelli P, Cheli E, Guarini R, Bacci ML, Mancini M, Marcuzzo C, Morrone MC, Parisi G, Pasquino G, Patrono C, Curzio AQ, Remuzzi G, Roncaglia A, Schiaffino S, Vineis P, R. on behalf of the COVID-19 Commission of 
AccademiaNazionaledeiLincei (2021) COVID-19 vaccines: where we stand and challenges ahead. Cell Death Differ. 28:626-639. https://doi.org/10.1038/s41418-020-00720-9

14. Colson P, Rolain JM, Raoult D (2020) Chloroquine for the 2019 novel coronavirus SARS-CoV-2. Int J Antimicrob Agents 55:105923. https://doi.org/10.1016/j.ijantimicag.2020.105923

15. Vincent MJ, Bergeron E, Benjannet S, Erickson BR, Rollin PE, Ksiazek TG, Seidah NG, Nichol ST (2005) Chloroquine is a potent inhibitor of SARS coronavirus infection and spread. Virol. J. 2:69. https://doi.org/10.1186/1743-422X-2-69

16. Touret F, de Lamballerie $X$ (2020) Of chloroquine and COVID19. Antiviral Res. 177:104762. https://doi.org/10.1016/j.antiviral. 2020.104762

17. Savarino A, Di Trani L, Donatelli I, Cauda R, Cassone A (2006) New insights into the antiviral effects of chloroquine. Lancet Infect. Dis. 6:67-69. https://doi.org/10.1016/S1473-3099(06) 70361-9

18. Wu R, Wang L, Kuo H-CD, Shannar A, Peter R, Chou PJ, Li S, Hudlikar R, Liu X, Liu Z, Poiani GJ, Amorosa L, Brunetti L, Kong A-N (2020) An update on current therapeutic drugs treating COVID-19. Curr. Pharmacol. Reports. 6:56-70. https://doi.org/ 10.1007/s40495-020-00216-7

19. Ko W-C, Rolain J-M, Lee N-Y, Chen P-L, Huang C-T, Lee P-I, Hsueh P-R (2020) Arguments in favor of remdesivir for treating SARS-CoV-2 infections. Int. J. Antimicrob. Agents. 55:105933. https://doi.org/10.1016/j.ijantimicag.2020.105933

20 Lai CC, Shih TP, Ko WC, Tang HJ, Hsueh PR (2020) Severe acute respiratory syndrome coronavirus 2 (SARS-CoV-2) and coronavirus disease-2019 (COVID-19): The epidemic and the challenges. Int. J. Antimicrob. Agents. 55:105924. https://doi.org/10.1016/j. ijantimicag.2020.105924

21. Al-Zaqri N, Pooventhiran T, Alsalme A, Warad I, John AM, Thomas R (2020) Structural and physico-chemical evaluation of melatonin and its solution-state excited properties, with emphasis on its binding with novel coronavirus proteins. J. Mol. Liq. 318:114082. https://doi.org/10.1016/j.molliq.2020.114082

22. Al-Zaqri N, Pooventhiran T, Alharthi FA, Bhattacharyya U, Thomas R (2020) Structural investigations, quantum mechanical studies on proton and metal affinity and biological activity predictions of selpercatinib. J. Mol. Liq. 325:114765. https://doi.org/10. 1016/j.molliq.2020.114765

23. Alsalme A, Pooventhiran T, Al-Zaqri N, Rao DJ, Rao SS, Thomas R (2020) Modelling the structural and reactivity landscapes of tucatinib with special reference to its wavefunction-dependent properties and screening for potential antiviral activity. J. Mol. Model. 26:341. https://doi.org/10.1007/ s00894-020-04603-1

24. Jiang Y, Liu L, Manning M, Bonahoom M, Lotvola A, Yang Z, Yang Z-Q (2020) Structural analysis, virtual screening and molecular simulation to identify potential inhibitors targeting 2'-O-ribose methyltransferase of SARS-CoV-2 coronavirus. J. Biomol. Struct. Dyn. 4:1-16. https://doi.org/10.1080/07391102. 2020.1828172

25. Frisch MJ, Trucks GW, Schlegel HB, Scuseria GE, Robb MA, Cheeseman JR, Scalmani G, Barone V, Mennucci B, Petersson GA, Nakatsuji H, Caricato M, Li X, Hratchian HP, Izmaylov AF, Bloino J, Zheng G, Sonnenberg JL, Hada M, Ehara M, Toyota K, Fukuda R, Hasegawa J, Ishida M, Nakajima T, Honda Y, Kitao O, Nakai H, Vreven T, Montgomery JA Jr, Peralta JE, Ogliaro F, Bearpark M, Heyd JJ, Brothers E, Kudin KN, Staroverov VN, Kobayashi R, Normand J, Raghavachari K, Rendell A, Burant JC, Iyengar SS, Tomasi J, Cossi M, Rega N, Millam JM, Klene M, Knox JE, Cross JB, Bakken V, Adamo C, Jaramillo J, Gomperts R, Stratmann RE, Yazyev O, Austin AJ, Cammi R, Pomelli C, Ochterski JW, Martin RL, Morokuma K, Zakrzewski VG, Voth GA, Salvador P, Dannenberg JJ, Dapprich S, Daniels AD, Farkas
O, Foresman JB, Ortiz JV, Cioslowski J, Fox DJ (2013) Gaussian09 Revision D.01. Gaussian Inc, Wallingford

26. Orio M, Pantazis DA, Neese F (2009) Density functional theory. Photosynth. Res. 102:443-453. https://doi.org/10.1007/ s11120-009-9404-8

27. Yanai T, Tew DP, Handy NC (2004) A new hybrid exchange-correlation functional using the Coulomb-attenuating method (CAMB3LYP). Chem. Phys. Lett. 393:51-57. https://doi.org/10.1016/J. CPLETT.2004.06.011

28 O'boyle NM, Tenderholt AL, Langner KM (2008) CCLIB: A library for package-independent computational chemistry algorithms. J Comput Chem 29:839-845. https://doi.org/10.1002/jcc. 20823

29. Lu T, Chen F (2012) Multiwfn: A multifunctional wavefunction analyzer. J. Comput. Chem. 33:580-592. https://doi.org/10.1002/ jcc. 22885

30. Parr RG, Pearson RG (1983) Absolute hardness: companion parameter to absolute electronegativity. J. Am. Chem. Soc. 105:7512-7516. https://doi.org/10.1021/ja00364a005

31. Johnson ER, Keinan S, Mori-Sánchez P, Contreras-García J, Cohen AJ, Yang W (2010) Revealing noncovalent interactions. J. Am. Chem. Soc. 132:6498-6506. https://doi.org/10.1021/ja100 936w

32. Burley SK, Berman HM, Bhikadiya C, Bi C, Chen L, Di Costanzo L, Christie C, Dalenberg K, Duarte JM, Dutta S, Feng Z, Ghosh S, Goodsell DS, Green RK, Guranović V, Guzenko D, Hudson BP, Kalro T, Liang Y, Lowe R, Namkoong H, Peisach E, Periskova I, Prlić A, Randle C, Rose A, Rose P, Sala R, Sekharan M, Shao C, Tan L, Tao Y-P, Valasatava Y, Voigt M, Westbrook J, Woo J, Yang H, Young J, Zhuravleva M, Zardecki C (2018) RCSB Protein Data Bank: biological macromolecular structures enabling research and education in fundamental biology, biomedicine, biotechnology and energy. Nucleic Acids Res. 47:D464-D474. https://doi.org/ 10.1093/nar/gky1004

33. Stewart JJP (1989) Optimization of parameters for semiempirical methods I. Method. J. Comput. Chem. 10:209-220. https://doi. org/10.1002/jcc.540100208

34. Jin Z, Du X, Xu Y, Deng Y, Liu M, Zhao Y, Zhang B, Li X, Zhang L, Peng C, Duan Y, Yu J, Wang L, Yang K, Liu F, Jiang R, Yang X, You T, Liu X, Yang X, Bai F, Liu H, Liu X, Guddat LW, Xu W, Xiao G, Qin C, Shi Z, Jiang H, Rao Z, Yang $\mathrm{H}$ (2020) Structure of Mpro from SARS-CoV-2 and discovery of its inhibitors. Nature. 582:289-293. https://doi.org/10.1038/ s41586-020-2223-y

35. Mesecar AD (2020) RCSB PDB - 6W63: Structure of COVID19 main protease bound to potent broad-spectrum non-covalent inhibitor X77. RCSB. https://doi.org/10.2210/pdb6W63/pdb

36. Trott O, Olson AJ (2010) AutoDock Vina: improving the speed and accuracy of docking with a new scoring function, efficient optimization, and multithreading. J. Comput. Chem. 31:455-61. https://doi.org/10.1002/jcc.21334

37 Trott O, Olson AJ (2009) AutoDock Vina: Improving the speed and accuracy of docking with a new scoring function, efficient optimization, and multithreading. J. Comput. Chem. 31:455-461. https://doi.org/10.1002/jcc.21334

38. Discovery Studio BIOVA, Discov. Stud. Client V17, San Diego, Dassault Syst. (2017).

39. Schrödinger Release 2019-3: Desmond Molecular Dynamics System, (2019).

40. Kevin J. Bowers, Edmond Chow, Huafeng Xu, Ron O. Dror, Michael P. Eastwood, Brent A. Gregersen, John L. Klepeis, Istvan Kolossvary, Mark A. Moraes, Federico D. Sacerdoti, John K. Salmon, Yibing Shan, David E. Shaw, Scalable algorithms for molecular dynamics simulations on commodity clusters, in: Barbara Horner-Miller (Ed.), Proc. ACM/IEEE Conf. Supercomput. 
(SC06), Tampa, Florida, 2006, Novemb. 11-17, [publisher not identified], Tampa, Florida, 2006.

41. Schrödinger Release 2020-3: Maestro, (2020).

42. Harder E, Damm W, Maple J, Wu C, Reboul M, Xiang JY, Wang L, Lupyan D, Dahlgren MK, Knight JL, Kaus JW, Cerutti DS, Krilov G, Jorgensen WL, Abel R, Friesner RA (2016) OPLS3: A force field providing broad coverage of drug-like small molecules and proteins. J. Chem. Theory Comput. 12:281-296. https://doi. org/10.1021/acs.jctc.5b00864

43. Martyna GJ, Tobias DJ, Klein ML (1994) Constant pressure molecular dynamics algorithms. J. Chem. Phys. 101:4177-4189. https://doi.org/10.1063/1.467468

44. Mary YS, Miniyar PB, Mary YS, Resmi KS, Panicker CY, Armaković S, Armaković SJ, Thomas R, Sureshkumar B (2018) Synthesis and spectroscopic study of three new oxadiazole derivatives with detailed computational evaluation of their reactivity and pharmaceutical potential. J. Mol. Struct. 1173:469-480. https:// doi.org/10.1016/j.molstruc.2018.07.026

45. Hossain M, Thomas R, Mary YS, Resmi KS, Armaković S, Armaković SJ, Nanda AK, Vijayakumar G, Van Alsenoy C (2018) Understanding reactivity of two newly synthetized imidazole derivatives by spectroscopic characterization and computational study. J. Mol. Struct. 1158:176-196. https://doi.org/10.1016/j. molstruc.2018.01.029

46. Thomas R, Hossain M, Mary YS, Resmi KS, Armaković S, Armaković SJ, Nanda AK, Ranjan VK, Vijayakumar G, Van Alsenoy C (2018) Spectroscopic analysis and molecular docking of imidazole derivatives and investigation of its reactive properties by DFT and molecular dynamics simulations. J. Mol. Struct. 1158:156-175. https://doi.org/10.1016/J.MOLSTRUC.2018.01. 021

47. Hosna S, Janzen DE, Mary YS, Resmi KS, Thomas R, Mohamed R, Wajda S (2018) Molecular structure, spectroscopic, dielectric and thermal study, nonlinear optical properties, natural bond orbital, HOMO-LUMO and molecular docking analysis of (C6Cl2O4) (C10H14N2F)2.2H2O. Spectrochim Acta Part A Mol Biomol Spectrosc 204:328-339. https://doi.org/10.1016/J.SAA. 2018.06.062

48. Domingo L, Ríos-Gutiérrez M, Pérez P (2016) Applications of the conceptual density functional theory indices to organic chemistry reactivity. Molecules. 21:748. https://doi.org/10.3390/molecules2 1060748

49. De Proft F, Sablon N, Tozer DJ, Geerlings P (2007) Calculation of negative electron affinity and aqueous anion hardness using Kohn-Sham HOMO and LUMO energies. Faraday Discuss. Royal Society of Chemistry, London, pp 151-159. https://doi.org/10. 1039/b605302p

50. Chattaraj PK, Sarkar U, Roy DR (2006) Electrophilicity index. Chem. Rev. 106:2065-2091. https://doi.org/10.1021/cr040109f

51 Chattaraj PK, Giri S (2009) Electrophilicity index within a conceptual DFT framework. Annu Rep Prog Chem Sect C Phys Chem 105:13-39. https://doi.org/10.1039/B802832J

52. Parthasarathi R, Subramanian V, Roy DR, Chattaraj PK (2004) Electrophilicity index as a possible descriptor of biological activity. Bioorg. Med. Chem. 12:5533-5543. https://doi.org/10.1016/j. bmc.2004.08.013

53 Parr RG, Szentpály LV, Liu S (1999) Electrophilicity index. J Am Chem Soc 121:1922-1924. https://doi.org/10.1021/ja983494x

54. Politzer P, Abu-Awwad F, Murray JS (1998) Comparison of density functional and Hartree-Fock average local ionization energies on molecular surfaces. Int. J. Quantum Chem. 69:607-613. https://doi.org/10.1002/(SICI)1097-461X(1998)69:4\%3c607:: AID-QUA18\%3e3.0.CO;2-W

55. Politzer P, Laurence PR, Jayasuriya K (1985) Molecular electrostatic potentials: an effective tool for the elucidation of biochemical phenomena. Environ. Health Perspect. 61:191-202. https://doi.org/10.1289/ehp.8561191

56. Murray JS, Seminario JM, Politzer P, Sjoberg P (1990) Average local ionization energies computed on the surfaces of some strained molecules. Int. J. Quantum Chem. 38:645-653. https:// doi.org/10.1002/qua.560382462

57. Politzer P, Murray JS (2002) The fundamental nature and role of the electrostatic potential in atoms and molecules. Theor. Chem. Acc. 108:134-142. https://doi.org/10.1007/s00214-002-0363-9

58 Politzer P, Murray JS (2018) An Occam's razor approach to chemical hardness: lex parsimoniae. J Mol Model 24:332. https://doi. org/10.1007/s00894-018-3864-8

59. Politzer P, Murray JS, Bulat FA (2010) Average local ionization energy: a review. J. Mol. Model. 16:1731-1742. https://doi.org/ 10.1007/s00894-010-0709-5

60. Politzer P, Lane P, Concha MC (2002) Atomic and molecular energies in terms of electrostatic potentials at nuclei. Int. J. Quantum Chem. 90:459-463. https://doi.org/10.1002/qua.10105

61. Barone V, Cossi M, Tomasi J (1997) A new definition of cavities for the computation of solvation free energies by the polarizable continuum model. J. Chem. Phys. 107:3210-3221. https://doi.org/ 10.1063/1.474671

62. Cossi M, Barone V, Cammi R, Tomasi J (1996) Ab initio study of solvated molecules: a new implementation of the polarizable continuum model. Chem. Phys. Lett. 255:327-335. https://doi. org/10.1016/0009-2614(96)00349-1

63. Klamt A, Moya C, Palomar J (2015) A Comprehensive comparison of the IEFPCM and SS(V)PE Continuum solvation methods with the COSMO approach. J. Chem. Theory Comput. 11:4220 4225. https://doi.org/10.1021/acs.jctc.5b00601

64. Glendening, F.W.E.D., Reed, A.E., Carpenter, J.E.: NBO 3.1, (2003).

65. Jeeva S, Muthu S, Thomas R, Raajaraman BR, Mani G, Vinitha G (2020) Co-crystals of urea and hexanedioic acid with third-order nonlinear properties: an experimental and theoretical enquiry. J. Mol. Struct. 1202:127237. https://doi.org/10.1016/j.molstruc. 2019.127237

66. Sheena Mary Y, Shyma Mary Y, Thomas R, Resmi KS, Narayana B, Samshuddin S, Sarojini BK (2019) Spectroscopic and theoretical studies of potential anti-inflammatory polycyclic aromatic fluorophenyl substituted acyclic and heterocyclic analogues synthesized from 4,4'-difluorophenylchalcone. Polycycl Aromat Compd 1:1-13. https://doi.org/10.1080/10406638.2019.1699836

67. Al-Otaibi JS, Mary YS, Armaković S, Thomas R (2020) Hybrid and bioactive cocrystals of pyrazinamide with hydroxybenzoic acids: detailed study of structure, spectroscopic characteristics, other potential applications and noncovalent interactions using SAPT. J. Mol. Struct. 1202:127316. https://doi.org/10.1016/j. molstruc.2019.127316

68. Beegum S, Mary YS, Mary YS, Thomas R, Armaković S, Armaković SJ, Zitko J, Dolezal M, Van Alsenoy C (2020) Exploring the detailed spectroscopic characteristics, chemical and biological activity of two cyanopyrazine-2-carboxamide, derivatives using experimental and theoretical tools. Spectrochim Acta Part A Mol Biomol Spectrosc. 224:1-13. https://doi.org/10.1016/j.saa. 2019.117414

69. Thomas R, Varghese E, Thomas ME, George J, Vijayakumar G (2015) Time dependent density functional study on the electronic spectra of some derivatives of triafulvalene. Can. Chem. Trans. 3:438-435

70. Thomas R, Mary YS, Resmi KS, Narayana B, Sarojini SBK, Armaković S, Armaković SJ, Vijayakumar G, Van Alsenoy C, Mohan BJ (2019) Synthesis and spectroscopic study of two new pyrazole derivatives with detailed computational evaluation of their reactivity and pharmaceutical potential. J. Mol. Struct. 1181:599-612. https://doi.org/10.1016/j.molstruc.2019.01.014 
71. Matondo A, Thomas R, Tsalu PV, Mukeba CT, Mudogo V (2019) $\alpha$-methylation and $\alpha$-fluorination electronic effects on the regioselectivity of carbonyl groups of uracil by $\mathrm{H}$ and triel bonds in the interaction of $\mathrm{U}, \mathrm{T}$ and $5 \mathrm{FU}$ with $\mathrm{HCl}$ and $\mathrm{TrH} 3(\mathrm{Tr}=\mathrm{B}, \mathrm{Al})$. J. Mol. Graph. Model. 88:237-246

72 Sheena Mary Y, Ertan-Bolelli T, Thomas R, Krishnan AR, Bolelli K, Kasap EN, Onkol T, Yildiz I (2019) Quantum mechanical studies of three aromatic halogen-substituted bioactive sulfonamidobenzoxazole compounds with potential light harvesting properties. Polycycl Aromat Compd. https://doi.org/10.1080/10406638.2019. 1689405

73. Thomas R, Mary YS, Resmi KS, Narayana B, Sarojini BK, Vijayakumar G, Van Alsenoy C (2019) Two neoteric pyrazole compounds as potential anti-cancer agents: synthesis, electronic structure, physico-chemical properties and docking analysis. J. Mol. Struct. 1181:455-466

74. Mary YS, Mary YS, Thomas R, Narayana B, Samshuddin S, Sarojini BK, Armaković S, Armaković SJ, Pillai GG (2019) Theoretical studies on the structure and various physico-chemical and biological properties of a terphenyl derivative with immense antiprotozoan activity. Polycycl Aromat Compd In Press. https://doi. org/10.1080/10406638.2019.1624974

75. Rao DJ, Mary YS, Mary YS, Resmi KS, Thomas R (2019) Structure, spectral features, bioactivity and light harvesting properties of methyl and dimethyl anthracene: experimental and first principle studies. Polycycl. Aromat. Compd. 1:1-15

76 Al-Otaibi JS, Sheena Mary Y, Shyma Mary Y, Panicker CY, Thomas R (2019) Cocrystals of pyrazinamide with p-toluenesulfonic and ferulic acids: DFT investigations and molecular docking studies. J Mol Struct 1175:916-926. https://doi.org/10.1016/j. molstruc.2018.08.055

77. Afzal A, Thayyil MS, Shariq M, Mary YS, Resmi KS, Thomas R, Islam N, Abinu AJ (2019) Anti-cancerous brucine and colchicine: experimental and theoretical characterization. ChemistrySelect. 4:11441-11454. https://doi.org/10.1002/slct.201902698

78. Al-Otaibi JS, Mary YS, Mary YS, Thomas R (2019) Quantum mechanical and photovoltaic studies on the cocrystals of hydrochlorothiazide with isonazid and malonamide. J. Mol. Struct. 1197:719-726. https://doi.org/10.1016/j.molstruc.2019.07.110

79 Al-Otaibi JS, Mary YS, Thomas R, Narayana B (2020) Theoretical studies into the spectral characteristics, biological activity, and photovoltaic cell efficiency of four new polycyclic aromatic chalcones. Polycycl. Aromat. Compd. 1:1-15. https://doi.org/10. 1080/10406638.2020.1747097

80 Mascarenhas AMS, Almeida RBM, Araujo Neto MF, Mendes GO, Cruz JN, Santos CBR, Botura MB, Leite FHA (2020) Pharmacophore-based virtual screening and molecular docking to identify promising dual inhibitors of human acetylcholinesterase and butyrylcholinesterase. J. Biomol. Struct. Dyn. 1:1-10. https://doi. org/10.1080/07391102.2020.1796791

81 Neto RAM, Santos CBR, Henriques SVC, Machado LO, Cruz JN, Silva CHTP, Federico LB, Oliveira EHC, Souza MPC, Silva PNB, Taft CA, Ferreira IM, Gomes MRF (2020) Novel chalcones derivatives with potential antineoplastic activity investigated by docking and molecular dynamics simulations. J. Biomol. Struct. Dyn. 1:1-13. https://doi.org/10.1080/07391102.2020.1839562

82. Santos CBR, Santos KLB, Cruz JN, Leite FHA, Borges RS, Taft CA, Campos JM, Silva CHTP (2021) Molecular modeling approaches of selective adenosine receptor type $2 \mathrm{~A}$ agonists as potential anti-inflammatory drugs. J. Biomol. Struct. Dyn. 39:3115-3127. https://doi.org/10.1080/07391102.2020.1761878

83. Oliveira M, Cruz JN, Costa W, Silva SG, Brito MP, Menezes SAF, Jesus Chaves Neto AM, Aguiar Andrade EH, Carvalho Junior RN (2020) Chemical composition, antimicrobial properties of siparuna guianensis essential oil and a molecular docking and dynamics molecular study of its major chemical constituent. Molecules. 25:3852. https://doi.org/10.3390/molecules25173852

84 Araújo PHF, Ramos RS, da Cruz JN, Silva SG, Ferreira EFB, de Lima LR, Macêdo WJC, Espejo-Román JM, Campos JM, Santos CBR (2020) Identification of potential COX-2 inhibitors for the treatment of inflammatory diseases using molecular modeling approaches. Molecules. 25:184183. https://doi.org/10.3390/molec ules25184183

Publisher's Note Springer Nature remains neutral with regard to jurisdictional claims in published maps and institutional affiliations. 